\title{
Surfaces
}

\section{Answering the Question: What is an Intellectual?}

\section{Gary Hall}

Volume 6, 1996

LES ÉCONOMIES DISCURSIVES DU SAVOIR ET DE LA CULTURE DANS

LE SILLAGE DE L'OEUVRE DE BILL READINGS

THE DISCURSIVE ECONOMIES OF KNOWLEDGE AND CULTURE,

WITH CONSTANT REFERENCE TO THE WORK OF BILL READINGS

URI : https://id.erudit.org/iderudit/1064857ar

DOI : https://doi.org/10.7202/1064857ar

Aller au sommaire du numéro

Éditeur(s)

Les Presses de l’Université de Montréal

ISSN

1188-2492 (imprimé)

1200-5320 (numérique)

Découvrir la revue

Citer cet article

Hall, G. (1996). Answering the Question: What is an Intellectual? Surfaces, 6. https://doi.org/10.7202/1064857ar 


\section{Answering the Question: What is an Intellectual}

Gary Hall

University of Teesside

School of Law, Humanities \& International Studies

Surfaces Vol. VI. 212 (v.1.0A - 22/12/1996) - ISSN:

1188-2492

Copyright for texts published in Surfaces remains the property of authors. However, any further publication should be accompanied by an acknowledgement of Surfaces as the place of initial publication.

intellectual... a person possessing or supposed to possess superior powers of intellect.

OED

'...after '68 people were saying that nobody could speak for anybody else;

expression was not something that could be monopolized.

We were asked to leave behind our role of subjects of knowledge, our role of teachers, etc. Speech, it was said, had been sold out.

All this was doubtless utopian. It was the utopia of '68, which blurred all the contours. It's extremely difficult, after this, to take up, once again, the position of the intellectual

who is conscious of himself. What is an intellectual? How can he claim to speak in anyone else's name?

Here we have a really radical question?'

Jean Baudrillard, Baudrillard Live[ 1 ] 
At least since Plato, intellectuals have portrayed themselves as vital to the good of humanity, and have done so in ways that depict them as the consciousness of society, representative spokesmen who act as the guardians of truth and justice for all. This figure occurs in Kant's 'image of the ill-natured men who redeem our race as lawgivers and scholars'; [ $\underline{\mathbf{2}}$ ] and can be further traced right up to Gramsci's own variation on the theme - the 'organic intellectual' - and beyond.[ $\underline{\mathbf{3}}$ ] Of course, neither Plato nor Kant used the word 'intellectual' itself to refer to these representative 'leaders' or 'masters'. The term 'intellectual' did not emerge until the Dreyfus Affair in France in the late 1890s, many of the overtly political associations of this term not being acquired until much later still. Nevertheless, the figure of the person who identifies and identifies with a subject, 'man, humanity, the nation, the people, the proletariat, the creature, or some such entity... endowed with a universal value so as to describe and analyze a situation or a condition from this point of view and to proscribe what ought to be done in order for this subject to realise itself, or at least in order for its realisation to progress', was by then already firmly established.

This description of the intellectual as a person who identifies and identifies with a subject 'endowed with a universal value', occurs in an essay entitled 'Le Tombeau de l'intellectual', written by Jean-François Lyotard in the summer of 1983 for the French newspaper Le Monde.[ $\underline{\mathbf{4}}$ ] Developing ideas similar to those outlined in the The Postmodern Condition (still his best know work, at least in the English speaking world, and one to which I will return later), Lyotard argues that the grand narratives of emancipation and enlightenment which had previously legitimated the idea of the intellectual have undergone a process of fragmentation and decline in the 'postmodern' world of the late twentieth century. As a result, there is no 'universal subject-victim' (6) with which the intellectual can identify. The notion of the intellectual can consequently no longer be sustained. Quite simply, it 'belongs to another world' (7). And, indeed, it has become something of a commonplace in recent years to argue that the role of the intellectual is no longer desirable, or even possible. Somewhere in the second half of the century, changes are seen to have occurred in both history and society which have rendered the idea of the intellectual as the bearer of universal values, the representative of truth and justice for all, increasingly difficult to maintain. One of the most notable products and symptoms of these changes is what can, for shorthand, be called the current 'crisis' in Marxist and 
more widely Leftist thought (evident, over the last seven years, in the tearing down of the Berlin Wall, the challenge to the authorities in the People's Republic of China and the massacre in Tiananmen Square, the collapse of the Soviet Union, the declaration of independence of the Soviet Republics, the re-shaping of Eastern Europe, and the civil war in the former Yugoslavia). From this point of view, the figure of the engaged or politically committed writer and thinker epitomised by Jean-Paul Sartre is often as not seen as having come to an end with the events in Paris of May 1968. As Michel Foucault remarked, it was here that 'the intellectual discovered that the masses no longer needed him to gain knowledge: they know perfectly well without illusion; they know far better than he and they are certainly capable of expressing themselves'.[ $\underline{\mathbf{5}}$ ]

Despite its prevalence, however, there are a number of problems with the idea that the role of the intellectual is unsustainable in the postmodern world of the late twentieth century. For one thing, it is possible to show that the intellectual was already rendered problematic long before this, and that if certain premises associated with the decline of the intellectual can be found in the work of those labelled, or who label themselves, 'postmodern' (particularly Lyotard, Foucault and Derrida), a similar demonstration can be made with respect to earlier thinkers. For another, if over the last twenty-five years or so certain thinkers have initiated a discussion around the question of the intellectual, none of them, it seems to me, has actually abandoned or eliminated anything. This is not say that there never was such a thing as the intellectual. Nor do I want to simply reverse the myth of the intellectual's decline and fall: to suggest that reports of the intellectual's demise are premature, and that this figure is alive and well after all, and living in 1990s Britain. Rather what concerns me is the concept of the intellectual itself. We must, we are often told, either abandon the notion of the intellectual[ 6 ] or get back to it, to resurrect it, to breathe into it new life.[ 7 ] But what is this figure that is so confidently either revoked or invoked? What is an intellectual?

\section{Afterwords}

In an earlier essay I tried to show that this question cannot be answered from within the tradition of the intellectual, since it is only by neglecting this issue, by marginalizing the question of the intellectual, that 
intellectuals can retain their identities as intellectuals.[ $\underline{\mathbf{8}}$ ] Nor can this problem be resolved by adopting a position that is 'outside' or that comes 'after' this tradition. Any attempt to simply leave the intellectual behind is liable to be recuperated by the very tradition it seeks to escape in a blind and unconscious fashion, as the idea of the intellectual is the very thing that is used to get the whole process of producing a critique of the intellectual off the ground. Consequently, the last thing that is done away with in this context is the concept of the intellectual. What needs to be questioned first is the meaning of what it is to be an intellectual and to do intellectual work.

Now, this emphasis on what is peripheralized and excluded from accounts of the intellectual, along with the stress I have placed here on the problematic nature of grand narratives of the intellectual's rise and fall, suggests that much of my questioning of the intellectual is being carried out under the influence of 'poststructuralism'. And certainly 'post-structuralism' seems capable of offering a very different means of approaching the question of the intellectual. However, as Geoffrey Bennington points out, 'the label poststructuralist (which is not itself a post-structuralist label) cannot... be simply applied from a methodological or theoretical outside to designate a particular way of approaching a predefined question'.[ [ 9 ] 'Poststructuralism' raises problems of identity and legitimation it is hard to distinguish from those bound up with the question of the intellectual. In particular, the term 'post-structuralism' itself raises a number of questions concerning history and periodization which only add to those difficulties for the writing of any account of the intellectual already identified.

Post-structuralism, for example, as the prefix 'post -' suggests, is generally regarded as coming after structuralism; it is that which follows on from structuralism in a logical manner of linear historical progression. And yet, as Bennington goes on to show, post-structuralism may not just come after, it may also in a paradoxical sense come before. This is something that is also suggested by the prefix 'post-' . For this is a prefix and 'thus comes before and not after. The post is at the beginning, and precedes, in a certain linear order..., the name (structuralism, the modern) with respect to which it is thought to come after'.

But this idea that 'the post' comes before as well as after, at the beginning as well as the end, is not confined merely to clever word-play around the name 
'poststructuralism'. Bennington is able to identify a similar paradox in Lyotard' book on The Postmodern Condition.[ 10 ] At first, Lyotard seems to go along with the idea that the 'post-', in this case the post-modern, does indeed follow on from the modern in a logical sequence of historical progression. From this point of view, we encounter the post-modern condition 'as we enter so-called post-industrial society'. As Bennington observes, 'this move from modern to postmodern seems to go along with a certain view of technical and technological progress, notably in the domain of computer technology'. Grand narratives of scientific advancement and progress have now lost their legitimacy. And yet at the same time Lyotard's book also provides a rigorous critique of any such 'grand narrative' of historical development and progression. For is the argument that grand narratives are now no longer desirable or even possible not itself a grand narrative? Is such a narrative not more 'modern' than 'postmodern'? This is something that Lyotard himself acknowledges: both in a later definition of the postmodern:[ 11 ] and also in his essay 'Answering the Question: What is Postmodernism?', which forms an appendix to the English translation of the book. Here the postmodern no longer constitutes a 'grand narrative'; nor does it constitute a break or boundary-line separating the modern from the postmodern. 'A work can become modern', for Lyotard, 'only if it is first postmodern. Postmodernism thus understood is not modernism at its end, but in the nascent state, and this state is constant'.[ 12 ] As Bennington insists, 'the post does indeed come first, then'.

This analysis of the 'post' has significant implications for the account of the intellectual Lyotard provides in 'The Tomb of the Intellectual'. According to Lyotard here, 'one can be an intellectual without dishonour only if the wrong lies entirely on one side, if the victims are victims and the torturers inexcusable...'.[ 13 ] It is this criterion Lyotard sees Marx as fulfilling (although Marx, of course, never used the term intellectual himself), for 'it was in this sense that Marx denounced the pure and simple wrong done to the worker by the condition of wage slavery': 'Marx's denouncement was authorised by a universal subject to come'. And it is precisely this 'authority [that] has disappeared', for Lyotard, in the postmodern world of the late twentieth century, as 'the signs that could legitimate the thought of such a subject have become more and more hard to find' (6). Lyotard consequently contrasts Marx favourably with Sartre, regarding the latter's attempt to continue to operate as an intellectual in a world where there is no longer a 
'universal subject-victim' as both misleading and dangerous. And yet the rigorous critique of any such 'grand narrative' of historical 'decline' Lyotard provides in the appendix to The Postmodern Condition implies that Marx's activity as an intellectual is already difficult and dangerous; and that a 'severe reexamination' such as that which 'postmodernity imposes on the thought of the Enlightenment, on the idea of a unitary end of history and of a subject' [ $\underline{\mathbf{1 4}}]$ is already at work in the thought of those intellectuals associated with a supposedly more unified and 'universal' age that has now passed. This is a point that is made explicitly by Lyotard in a further definition of postmodernism this time characterized, not as a 'new age', but as the 'rewriting of some of the features claimed by modernity'; a process of rewriting, furthermore, that 'has been at work, for a long time now, in modernity itself.[ 15 ] From this perspective, far from offering a contrast to the condition of the intellectual in the 'postmodern' world, the 'classical' or 'universal' intellectual can be seen to contain a similar lack of legitimacy. It is not that the intellectual was somehow legitimate before the 'middle of the twentieth century' (6) and afterwards was not. Rather, the mythical, fictitious, fantasmatic elements associated with so-called 'postmodern' or 'poststructuralist' thought are already present in the 'classical' or 'universal' intellectual. The post comes first in this respect, too.

At this point it becomes clear that the task of producing an account of history of the intellectual is rendered problematic not just by differences, but by a great many continuities: between modernism and postmodernism, Marxism and post-structuralism, Germany and France, to name but a few. One effect of this is to place a question mark against the myth of 1968: the idea that it was at this point that the idea of the intellectual came to an end and was finally abandoned; and that poststructuralism - along with postmodernism - can be confined to a particular period, place or position that can be regarded as coming afterwards.[ $1 \mathbf{1 6}$ ] The idea of the intellectual, it can be seen, was already rendered problematic in discourses long before 1968. This is not to deny that something has changed; that there has been a history of both the intellectual and of the interrogation of the intellectual. Certainly during the 1960s and 1970s, the idea of the intellectual began to be dislodged from its privileged role, and an attitude of distrust towards all those who claimed to speak for the universal interests of 'man' began to be fostered instead. But it certain hypotheses associated with the decline of the intellectual can be identified 'in' Lyotard (under the influence, it is 
worth noting, of much earlier philosophies: Nietzsche, Freud, Heidegger, as well as, of course, Marx), a corresponding identification can be made in Marx. Here, too, one can find similar hypotheses and premises. Not the same ones, but similar ones.

Another is to complicate still further the reference to something called 'the intellectual'; to show once again that there has never simply been 'the intellectual'; that the idea of the intellectual has always contained an element of fiction; that there never was a 'classical' or 'universal' intellectual. This is not to imply that the intellectual always functioned, or was always seem to function, in the same way; that the intellectual has always been the same: simply that to account for these differences is an enormous question. Nor is this to suggest that the role of the intellectual has been, or now should be, abandoned. It is not my intention to go along with the claim that the idea of intellectual can no longer be sustained, that it is at the very least outdated, a dying breed, and that Sartre was the last of his kind. For one thing, this serves only to confirm the idea that, although there no longer is such a thing as an intellectual, there once was - with the result that the identity of the intellectual is reinforced even as it is being undermined. [ 17 ]

For another, this claim seems to me to be based on a false premise: the idea that for certain thinkers today, the role of the intellectual is no longer possible; that the intellectual has been pronounced dead, abandoned and done away with. This myth is perpetuated not only by those who see the apparent demise of the intellectual as a good thing, but also by those who regard the death of the intellectual as a threat. From this latter point of view, the perceived fall of the intellectual has been met by a promise of action: a call to rescue, revive or restore the intellectual in order to produce a new philosophy, a new world view. However, if over the last 25 years or so certain thinkers have opened up a discussion around the question of the intellectual, it does not seem to me that any of them have done away with anything.

There are at least two reasons for thinking this. Firstly, the figure of the 'classical' or 'universal' intellectual has certainly not been eliminated from the postmodern world of the late twentieth century. Many writers continue to act and think in this way.[ $1 \mathbf{8}$ ] What is more, this applies even to those who have sought to problematize the idea of the 'classical' or 'universal' intellectual, and to whom the label 'poststructuralist' can be or has been attached. 
Such thinkers in many respects continue to act as 'classical' or 'universal' intellectuals, although there are of course different things to be said here, according to the particular thinker in question, the stage of their development, the text examined, the strategy employed, and so on. We have already seen how Lyotard continues to act as a 'modernist' intellectual, while also, in his words, 'rewriting' the concept of both 'modernity' and the intellectual.[ 19 ] Another example, one which works to complicate still further any simple narrativization or periodization of the history of the intellectual, is provided by the theory of the 'specific intellectual' advocated by Michel Foucault.

\section{The not so 'specific intellectual'}

In an interview conducted in 1977 entitled 'Truth and Power', Foucault describes how, at least since the eighteenth century, Western culture has supported the right of the intellectual to speak, in the capacity of master, of a truth and justice which can and must be applied universally. This figure (which has Voltaire as its prototype), he terms a 'universal intellectual', seeing it as being derived from the 'jurist or notable', the 'man of justice, the man of law', who counterposes all the abuses of power and wealth with 'the universality of justice and the equity of an ideal law'. However, although an 'offspring of the jurist', the universal intellectual finds its 'fullest manifestation in the writer'. For it is the writer who is the supposed 'bearer of values and significations in which all can recognize themselves: 'the consciousness/conscience of us all'.[ $\underline{\mathbf{2 0}}$ ]

Although Foucault concedes in an earlier interview with Gilles Deleuze that the universal intellectual may have had a certain coherency in the past (Foucault cites three specific historical moments: 'after 1848, after the Commune, after 1940'), he nevertheless sees it as having come to an end with the events of 1968. In place of the 'universal' intellectual Foucault advocates the concept of the 'specific' intellectual, who is not a 'great writer' or 'genius', but 'a savant or expert' $(\mathrm{P} / \mathrm{K}, 128)$ with a 'direct and localized relation' $(\mathrm{P} / \mathrm{K}, 128)$ to knowledge.

The specific intellectual thus represents a 'new mode of the connection between theory and practice' $(\mathrm{P} / \mathrm{K}, 126)$. The specific intellectual does not attempt to act as the 'bearer of universal values': as, say, the representing or representative consciousness of a 'universality whose obscure, collective form is embodied in the proletariat'. 
According to Foucault, this latter idea belongs to a 'faded Marxism' (P/K, 126). Rather, the specific intellectual works to 'take power'[ 21 ] within 'specific sectors, at the precise points where their own conditions of life and work situate them (housing, the hospital, the asylum, laboratory, the university, family and sexual relations)' $(\mathrm{P} / \mathrm{K}, 126)$. 'In this sense theory does not express, translate, or serve to apply practice: it is practice. But it is local and regional.... and not totalizing. ... It is not to awaken consciousness ' (I.P., 208) that the specific intellectual struggles. Intellectual work is instead now 'an activity conducted alongside those who struggle for power, rather than consisting simply of their illumination from a safe distance' (I.P., 208); something which operates at a local level, in more immediate and concrete situations, and in particular institutions. And this includes the institution of the intellectual itself, for the function of the 'specific intellectual' is not only to take part in local struggles, but to combat his or her own previous incarnation as a universal intellectual: 'The intellectual's role is no longer to place himself somewhat ahead and to the side in order to express the stifled truth of the collectivity; rather, it is to struggle against the forms of power that transform him into its object and instrument in the sphere of knowledge , truth, consciousness, and discourse ' (I.P., 207-8). For '[the] idea of [the universal intellectuals'] responsibility for consciousness and discourse [itself] forms part of the system' (I.P., 207) of power.

As a result of this struggle against the intellectual's earlier role, Foucault's concept of the 'specific intellectual' is often regarded as working outside, and as coming after, the tradition of the 'classical', 'universal' intellectual 'who spoke the truth to those who had yet to see it, in the name of those who were forbidden to speak the truth' (I.P., 207). And yet it seems to me that for all this, Foucault's idea of the 'specific intellectual' upholds many of the concepts it purportedly wishes to challenge. Indeed, is this argument, whereby Foucault rejects the universal intellectual in favour of the specific intellectual, not itself a universal one? Certainly when Foucault argues against the universal intellectual, he does not to so as a 'specific intellectual'. Foucault's analysis of the 'universal intellectual' is itself the analysis of an 'universal intellectual', his concept of the specific intellectual a theory of the intellectual in general. As Mark Poster has observed, 'Foucault legislates in favour of the specific intellectual, the writer organically connected with an institution and group. Yet the negation he posits is universal. Anyone who maintains the stance of the universal is subject to the 
representational fallacy, but to attack this anyone requires a universal statement.[ $\underline{\mathbf{2 2}}$ ]

Foucault thus effectively contradicts his thesis on the universal intellectual. Although he describes the tradition of the universal intellectual as having come to an end over twenty-five years ago now, he himself continued to operate very much within this tradition. And nowhere more so, it seems to me, than in his construction of this history of the universal intellectual's rise and fall. For isn't it precisely this sort of grand totalizing narrative that is now no longer desirable, or even possible, for Foucault?[ $2 \mathbf{2 3}$ ]

Despite the apparently radical nature of Foucault's critique, the question that is left unasked here is that which deals with what it is to be an intellectual, to do intellectual work, to produce an analysis of the intellectual. And this creates difficulties for any situating of Foucault in a purely oppositional relation to the 'classical' or 'universal' intellectual. Foucault's notion of the 'specific intellectual' depends for much of its identity as a 'new' theory of the intellectual on its contrast to the 'universal' model. Yet we can see that the difference between the theories of the 'universal' and the 'specific' intellectual may not be that great. At the very least, they cannot be contrasted in terms of a simple 'universal'/'specific' opposition, since Foucault's conception of the 'specific' intellectual itself contains a number of 'classical', 'universal' features; this relation being complicated still further by the fact that Sartre, who is often regarded as the contemporary representative of the 'universal' intellectual, came, with his concept of the 'friend of the people', to adopt a notion of the intellectual that was similar in many respects to Foucault's concept of the specific intellectual. The problems of the universal intellectual, then, cannot be avoided simply by attempting to adopt a position 'outside' of this tradition. Rather the question that needs to be raised is what, in the last instance, supports this critique of the universal intellectual? What is its status? What validity does it have?

\section{Re-thinking the political intellectual}

If certain thinkers have opened up a discussion around the question of the intellectual, one reason I believe the intellectual has not been abandoned or eradicated is that the 'classical' or 'universal' intellectual can still be seen 
to be alive and well in the postmodern world of the late twentieth century. A second is that, in spite of certain declarations about the effacement of the intellectual, this figure is never done away with by such thinkers.

Although the intellectual may be re-interpreted and reinscribed, it is never eradicated.

So far, I have concentrated predominantly on the traditional 'left' definition of the term 'intellectual'. This is the 'political' notion Stefan Collini associates primarily with French thought, [ $\underline{\mathbf{2 4}}$ ] and which, as we have seen, forms the basis of the respective accounts of both Lyotard and Foucault. This operates according to a Hegelian, dialectical model, in which two distinct and separate entities - in this case the intellectual and the universal subject (ie. 'the proletariat') - are set up in a relation of conflict and opposition (although there are of course many differences between these conceptions, particularly with regards to how this conflict is, or is not, resolved, as the case may be). My aim in doing so has been to make explicit some of the difficulties with this model of the intellectual and, in particular, to draw attention both to some of the things it depends upon but nevertheless leaves unthought, and the way in which the exclusion of these factors prevents it from asking (an therefore answering) the question 'What is an intellectual?'

The problem with this is that I am then left with the task of finding an alternative model of the intellectual from which this question can be asked. This is hard for the simple reason that Hegel's system already includes its negation. You cannot escape the dialectic simply by opposing it, for such opposition is always recuperable as part of the dialectic. Hence the way in which, as we have seen, attempts to reject this model of the intellectual invariably continue to operate very much according to a Hegelian, dialectical model.

Nevertheless, there is another model of the intellectual that can be adopted here. And it is, of course, this model that I have been following all along. This is that suggested by Jacques Derrida, who, instead of negating Hegel, works to interrupt him from within by following him 'to the end, without reserve, to the point of agreeing with him against himself'. [ 25 ] By proceeding according to a nonoppositional difference in this way, Derrida is able to demonstrate how Hegel's work already contains a different model of the dialectic: one which does not depict the relation between 'opposites' as a simple contradiction, but which rather inscribes into the dialectic a radical nondialectical alterity.[ $\underline{\mathbf{2 6}}$ ] 
As such, Derrida offers a very different model for the intellectual. Derrida's description of Nelson Mandela in 'The Laws of Reflection' provides a specific example. In marked contrast to the traditional 'political' intellectual, Mandela neither passively accepts the law which condemns him, nor attempts to adopt a transcendental position outside that law in an effort to negate or reject it. Rather (in a descriptive that could equally serve as an account of Derrida's own activity as an 'intellectual') Mandela's 'acts, his demonstrations, his speeches, his strategy' work as a 'line of reflection' drawing attention to the 'spectacular paradoxes in the experience of the law'. Mandela in this way 'respects the logic of the legacy [of the Magna Charta, the Universal Declaration of the Rights of Man, and also of parliamentary democracy] enough to turn it upon occasion against those who claim to be its guardians, enough to reveal, despite and against the usurpers, what has never yet been seen in the inheritance: enough to give birth, by the unheard-of act of reflection, to what had never seen the light of day'.[ 2 7 ]

But just as Derrida shows how 'his' conception of the dialectic is always already at work within the texts of Hegel (the 'post' coming first once again), so this 'Derridean' model of the intellectual cannot be simply located 'after' and 'outside' the traditional, 'political' model. These two models cannot themselves to set up in terms of a simple opposition, such as that which is often attempted with regards to Foucault and Sartre, as the 'political' conception of the intellectual already contains this 'different' model. Let me illustrate this by turning to what is perhaps the most famous example of the political intellectual of the twentieth-century: Jean-Paul Sartre's concept of the 'classical' intellectual.

In 'A Plea for Intellectuals', [ $\underline{\mathbf{2 8}}$ ] Sartre provides a detailed description of the figure he condemned after the events of 1968 as the 'classical' intellectual. The people he terms 'intellectuals' belong to a socio-professional group made up of what Sartre calls the 'theoreticians of practical knowledge'. 'All praxis has several moments to it' (231), according to Sartre. However, the division of labour that operates in modern society means that 'the different tasks which. taken together, constitute praxis' are separated out and assigned to different groups of specialists. The field of 'practical knowledge' is assigned to one such group. These particular specialists have control over neither the assessment of the uses to which their knowledge is put - this comes under the jurisdiction of the ruling classes - nor its realisation - this is left to 
the working classes (Sartre cites as an exception the case of the surgeon). The social function assigned to these specialists is simply the study and critical examination of the means to these ends - the 'field of possibilities' (232)

Sartre takes great care to distinguish this 'theoretician' from the intellectual. Theoreticians are not intellectuals, although it is from this group that intellectuals are for the most part recruited. 'The intellectual', for Sartre, is 'someone who becomes aware of the opposition, both within himself and within society, between a search for practical truth (with all the norms it implies) and a ruling ideology (with its system of traditional values)' (246). If 'the technician of knowledge accepts the dominant ideology or adapts himself to it' (244), then he is not an intellectual. He is merely a subaltern functionary of the superstructure, a practical theoretician of the dominant class. But:
if the technician of practical knowledge becomes aware of the particularism of his ideology and cannot reconcile himself to it... then the agent of practical knowledge becomes a monster, that is to say an intellectual; someone who attends to what concerns him... and whom others refer to as man who interferes in what does not concern him. (244)

This is why, for Sartre, you can't have an intellectual who is not left-wing.[ $\mathbf{2 9}$ ] For the intellectual's consciousness of this contradiction - 'what Hegel called an unhappy consciousness (243) - is precisely what characterizes the intellectual as an intellectual.[ $\underline{\mathbf{3 0}}$ ]

The role of the intellectual, Sartre insists, is to liberate himself from this ideology. But he cannot do so simply be studying it, for 'it is his own ideology' (255). The only way the intellectual can really distance himself from the dominant ideology is 'by adopting the point of view of its most underprivileged members,.....(those) whose very existence contradicts it' (255/56). Intellectuals are in this way able to soothe their guilty consciences by using the knowledge and power they have acquired as members of the bourgeoisie against the bourgeoisie, and their own 'petite-bourgeoisie conditioning' (261). But although the situation of the 'under-privileged classes', as Sartre calls them, is in contradiction with that of the bourgeoisie minority, and is in this respect the same as that of the intellectual, the underprivileged classes 'lack, or want of technical knowledge, a reflective consciousness of their situation' (265). Consequently, they cannot speak for 
themselves; they are too much the passive 'dupes' of bourgeois ideology. Rather, they need intellectuals to speak for them, and to give expression to their cause by revealing the true nature of their situation. Missing from this account, however, is an explanation for the intellectual's possession of this superior consciousness. What exactly legitimises the intellectual's claim to know more about the underprivileged classes than they do themselves, and to therefore be able to represent and speak for them?

Sartre himself explicitly acknowledges the intellectual's lack of legitimacy. As far as he is concerned, the intellectual, by definition, 'has a mandate from no one' (264). However, it is precisely the contradictory nature of the intellectual's situation that provides 'him' with a function. For 'on closer inspection we find that the intellectual's contradictions are the contradictions inherent in each one of us and in the whole society'. By striving to achieve a reflective consciousness of his situation, the intellectual 'makes an effort to achieve consciousness for all. Yet on closer inspection, we find that this only begs the question. For what evidence does Sartre have that the intellectual's contradictions are those of society as a whole? And by what means is this figure able to achieve a more 'reflective consciousness' (of both his or her own situation, and of society's fundamental contradictions) than anyone else? These questions are never raised by Sartre. Sartre merely takes it for granted that the intellectual can act as the 'guardian of fundamental ends (the emancipation, universalization and hence humanisation of man)' (266).

This failure on Sartre's part to pursue further the question of the intellectual's legitimacy has important consequences for those whom the intellectual claims to represent, as Lyotard and Foucault, among others, have both shown. For Sartre's Marxist narrative (to adopt Lyotard's terminology for a moment) can maintain its status only by preventing the underprivileged classes from becoming narrators themselves, restricting them instead to the positions of addressee and referent. Far from opening up the possibility of a radical politics, Sartre's claim to determine exclusively the meaning of capitalism and the proletariat only serves to eradicate the possibility of politics (politics, or rather the political, for Lyotard, being not a specific genre of activity which contains all others, but a heterogeneity of incommensurable genres which resists any such totalization).[ $\mathbf{3 1}$ ] Insofar as Sartre's discourse is presumed authoritative, the proletariat can only speak in accordance with that description. And since they are 
positioned here merely as the dumb referent of Sartre's discourse, they cannot speak at all. Sartre's conception of the intellectual thus stays firmly within the political structure of representation it is attempting to challenge. The intellectual ends up speaking for the underprivileged classes and imposing his or her views onto them in much the same way as bourgeois society does. The intellectual's is merely an alternative view, that is all. As a result, the underprivileged classes become the double victims of a terroristic domination; first by capitalist society; and secondly by the intellectual, who commits what Gilles Deleuze calls 'the indignity of speaking for others'.[ $\underline{32}$ ]

But this failure to question the intellectual's legitimacy also has important consequences for the identity of the intellectual itself. The intellectual is 'defined as a man who has achieved consciousness of his own constituent contradiction' (260). It is this superior 'reflective consciousness' that distinguishes the intellectual from both the theoretician of practical knowledge, and from the underprivileged classes. Whereas the intellectual possesses a true awareness of 'his' contradictions (which are also the 'fundamental contradictions' of society as a whole), the latter are merely the unknowing victims of those 'myths', values and traditions with which [the dominant class] seeks to infect other classes in order to ensure its hegemony' (246). But if the intellectual has no means of accounting for this difference, of justifying the superior reflectiveness of his or her consciousness, then the intellectual's knowledge begins to take on the appearance of what it claims not to be: the intellectual has as its foundation precisely that which it is supposed to be doing away with in the rest of society.

At this point, it is interesting to consider Sartre's own words on the subject of 'analyses which are quite admirable but which ultimately rest on no foundation at all', taken from an interview he gave only a few years after writing 'A Plea for Intellectuals'. For this, too, seems to be very much:

the kind of question where many intellectuals are too quick to take sides. Their being intellectuals ought to inhibit them from making up their minds one way or the other because they are supposed to bed on the side of truth, i.e. of the strict determination beforehand of the scope of possibility. But here one of the 'possibilities' is missing - namely knowledge, information. 
Making up your mind with full knowledge of the facts is fine. Making up your mind in a state of ignorance means backsliding into the particular. It means abandoning the defining criterion of the intellectual...[ $\underline{33}$ ]

The intellectual, then, is unable to live up to its own definition of itself (even by his own criteria, it seems, Sartre is not an intellectual). Instead, the intellectual depends for its identify on the very things which, by definition, the intellectual is supposed to question and illuminate; myth, values and traditions: ideology, in other words. Hence the way in which, as a number of critics have pointed out, Sartre adheres unquestioningly to the myth of the intellectual as a 'person possessing superior powers of intellect'; to the old-fashioned and deeply romantic separation of the critic and society, the outsider and his or her culture; and in particular, to the traditional metaphysical distinction between theory and practice.[ 34 ] Far from 'questioning [these] received truths and the accepted behaviour inspired by them' (230) - which is, after all, the role of the intellectual according to Sartre - he passively accepts this separating out of functions whereby theory is confined to one sphere and practice to another. Sartre's conception of the intellectual is consequently untenable: to use his own words against himself, it has abandoned the 'defining criterion of the intellectual'. The intellectual is merely 'supposed to possess superior powers of intellect'.

As a result, the intellectual can no longer be simply contrasted and opposed to the underprivileged classes on the basis of his (or her) possession of a 'superior' consciousness or 'intellect'. This notion of the intellectual is itself a form of myth, fiction, ideology. Indeed, one could go so far as to say that the intellectual has fiction as its very foundation. For in the act of founding itself, the intellectual produces, as much as it represents, the underprivileged classes and their universality via a twostage operation whereby the intellectual: first, identifies the underprivileged classes as a separate entity, distinct from the intellectual; and then, second, endows this separate entity with a universal value that is, as Mark Poster puts it, 'promptly stolen by the intellectual, who now claims consciousness of this universality'. The 'radical fiction' that lies at the heart of the intellectual is thus comprised of the way in which the intellectual claims merely to bed describing - as though it were simply a case of revealing the true nature of the underprivileged classes' situation, both to them and to society at large - what it is in fact in the act of producing. 
The 'intellectual's assertion of [the under privileged classes'] universality easily becomes an alibi for grasping power' that enables the intellectual to 'authorise', quite literally, his or herx own status as a guardian of universal knowledge.[ 35 ] The universality of the underprivileged classes that legitimates the universal intellectual is consequently produced by the universal intellectual itself. The intellectual authorises and legitimates itself, without the guarantee of a preexisting universal subject. In short, the intellectual is founded in itself and based on itself, the violence with which this legitimacy is maintained serving only to highlight the failure of this attempt at foundation.

\section{The beginning of the end}

Now, by and large, this analysis of the 'political', leftwing intellectual, epitomised by Sartre, represents nothing new. It has been conducted many times before, in many different guises, and is by now well known. But what has perhaps not been said so often before is that, followed through to the end, Sartre's account of the intellectual itself creates problems for this political, dialectical conception of the intellectual. Take the following passage from 'A Plea for Intellectuals', in which Sartre again draws attention to the contradictory nature of the intellectual's situation:

If the intellectual, who cannot be organically produced as such by the underprivileged classes, nevertheless seeks to rally to them in order to assimilate their objective intelligence and to inform his trained methods with their popular principles, he will promptly and justifiably encounter the distrust of those with whom he wishes to ally. In effect workers are bound to see him as a member of the middleclasses - in other words, of strata which are by definition accomplices of capital. The intellectual is thus necessarily separated by a gulf from those men whose point of view he wants to adopt - that of universalization... In point of fact it seems as if there is a vicious circle here: in order to struggle against the particularism of the dominant ideology, it is necessary to adopt the point of view of those very existence condemns it. But to adopt this point of view, an intellectual must never have been a petty-bourgeois, since his education has irretrievably infected him from the start. 
Moreover, since it is the contradiction between particularizing ideology and universalizing knowledge that makes a petty-bourgeois into an intellectual, to adopt this point of view it would be necessary not to be an intellectual. (257-258).

The intellectual, then, cannot overcome the condition of being 'what Hegel called and unhappy consciousness, that condition which creates so many problems for the intellectua; and which, in fact, actually defines the intellectual, for Sartre.[ $\underline{\mathbf{3 6}}$ ] If there was nothing to separate the intellectual from the underprivileged classes, if the 'gulf' between them was completely bridged, then there would no longer be a 'gulf'; nor would there be an intellectual. For the intellectual is born precisely out of this 'gulf', this 'opposition, both within himself and within society, between a search for practical truth... and a ruling ideology' (246). The intellectual is only an intellectual in so far as it is not absolute. The intellectual needs the promise (or the threat) of another, an outside, in order to actualise the process of struggle and desire which produces the intellectual itself.

The 'gulf' that separates the intellectual from the underprivileged classes cannot be completely bridged, then; the intellectual cannot be united with the underprivileged classes to produce 'a harmonious totality' (247). But neither can all the means of passing from one side of this 'gulf' to the other be completed closed. Theirs is not an absolute separation. If it was, there would be nothing for the intellectual to distinguish itself from, nothing for it to assimilate or appropriate, to lack or desire. Once again, there would no longer be an intellectual. The intellectual cannot be completely separated from the underprivileged classes because it is entirely dependent on them. It is only by means of the underprivileged classes, and the challenge they represent to the 'particularism of the dominant ideology', that the intellectual can be produced at all.

There is thus an inherent paradox in the intellectual's relation to the underprivileged classes. The underprivileged classes appear to be both vitally necessary and narcissistically conflictual. They are both positive and negative. On the one hand, it is only be being a member of the bourgeoisie, and thus 'being necessarily separated by a gulf from those men whose point of view he wants to adopt', that the intellectual can become aware of the 'contradiction between particularizing ideology and universal knowledge that 
makes a petty-bourgeois into an intellectual'. It is thus only by maintaining this 'gulf' that the intellectual can keep on being an intellectual. (Hence to cross this 'gulf', Sartre insists, 'it would be necessary not to be an intellectual'). And yet, as the same time, the intellectual is only an intellectual insofar as it crosses this 'gulf'. For it is only by traversing this 'gulf' in order to adopt the point of view of the underprivileged classes, that the intellectual can meet the defining criteria of the intellectual: that of being someone who struggles against the particularisms of the dominant ideology.

Here we are at the heart of the ambivalence of the relationship between the intellectual and the underprivileged classes. The 'gulf' that separates them, is also precisely what binds them together. It does not just separate, it is also a place of joining and communication.[ 37 ] The same fundamental social contradiction between 'particularizing ideology and universal knowledge' which keeps them apart, also produces the intellectual's project of rallying to the under-privileged classes, and hence the process of appropriation and assimilation from outside to inside which brings them together. The 'gulf' cannot be completely crossed, otherwise it wouldn't be a 'gulf'. Yet neither is it absolutely uncrossable. After all, a gulf is a gulf only if it can be crossed. The 'gulf' between the intellectual and the underprivileged classes is thus both crossed and maintained at the same time in a paradoxical structure. It appears to be a question neither of crossing nor not crossing the 'gulf' that exists between them. Rather, the intellectual crosses in the form of a non-crossing.

The struggle over the 'gulf' between the intellectual and the under-privileged classes is thus both a means of sustaining the intellectual's identity, and a means of problematizing it. Part of being an intellectual is struggling to become an intellectual by crossing this 'gulf'; but at the same time the only way the intellectual can be an intellectual is by not crossing this 'gulf', by not becoming an intellectual. This is not to suggest, however, that the project of rallying to the underprivileged classes is replaced by a process of continual struggle between the intellectual and underprivileged classes. Rather, the possibility of joining with the underprivileged classes is contained in this very struggle; just as this struggle is part of the process of joining underprivileged classes. Theirs is not a dualistic separation. The relation between the intellectual and the underprivileged classes cannot be set up in a binary fashion. If this 'contradiction' in the intellectual's situation means anything at all, it is that 
the 'gulf' that links the intellectual to, and separates the intellectual from, the under-privileged classes can be understood, not so much as a space between two distinct and contrasting entities, as an irresolvable fissure within the intellectual in which the under-privileged classes occupy the intellectual as its condition of 'possibility'.

The question with which I began - what is an intellectual? - can thus never be answered. This question is in fact a meaningless one. It makes sense only with regard to an at lease possible understanding of the intellectual's relation to the underprivileged classes. It is only because intellectuals continue to conceive this relation as external and as coming 'after' the formation of their own identities, that they can claim as their objective the understanding, the control, and even the undoing of this relation. This would of course be perfectly plausible given the traditional view of the intellectual. Here, the intellectual and the universal subject ('man, humanity, the nation, the people, the proletariat, the creature, or some such entity') are both predetermined in their constitution and their very relationship. Both occupy pre-given identities. It is just the nature of their relationship that causes problems. But we can now see that the intellectual does not come before this relation. Rather, it is this relation that causes the intellectual (and the universal subject) to appear. The intellectual is formed for born in the very process of its relation to this universal subject, in the very process of crossing the 'gulf' that separates them.

This explains why the intellectual can never know or account for its own origin; why Sartre can never account for the intellectual's difference from the underprivileged classes. This origin of the intellectual cannot be written without fiction, the intellectual's relation to the universal subject can never be understood, since it is precisely as a result of this relation that the intellectual emerges. It also explains why this relation can never be resolved; why this relation can never be displayed or removed from the definition of the intellectual. For it is this relation which creates so many problems for the intellectual, which makes the intellectual possible in the first place. The 'unhappy consciousness' is the 'necessary possibility' of the intellectual, to borrow Derrida's term.[ $\underline{38}$ ] The problem of the relation between the figure of the person who possesses or it 'supposed to possess superior powers of intellect' and a collective subject 'endowed with a universal value', is not something which creates difficulties for the intellectual only after its immaculate conception. It is not a complication which threatens the intellectual in its homogeneous self- 
identity. It is an originary complication, coming before the fiction of such a foundation as its condition of possibility. The beginning, the origin of the intellectual, is already inhabited by the end, by what comes afterwards[ $\underline{39}$ ]

\section{NOTES}

1. Jean Baudrillard, 'Intellectuals, Commitment and Political Power: Interview with Maria Shevtsova', Baudrillard Live: Selected Interviews (London: Routledge, 1993), 79

2. Immanuel Kant, Anthropology from a Pragmatic Point of View, trans. Victor Lyle Dowdell, revised and edited by Hans H. Rudnick (Carbondale Illinois: Southern Illinois University Press, 1978); cf. Paul A. Bové, Intellectuals in Power: A Genealogy of Critical Humanism (New York: Columbia University Press, 1986) xiv.

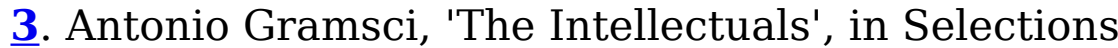
From the Prison Notebooks of Antonia Gramsci, ed. and trans. Quintin Hoare and Geoffrey Nowell-Smith (London: Lawrence and Wishart, 1971), 3-23

4. Jean-François Lyotard, (1983) 'The Tomb' of the Intellectual', Jean-François Lyotard: Political Writings, trans. Bill Readings and Kevin Paul Geiman (London: U.C.L. Press, 1993), 3.

5. Michel Foucault, 'Intellectuals and Power: A Conversation Between Michael Foucault and Gilles Deleuze', Language, Counter-Memory, Practice: Selected Essays and Interviews by Michael Foucault, Donald F. Bouchard ed., trans. D.F. Bouchard and Sherry Simon (Ithaca, New York: Cornell University Press, 1977), 205-217, 207.

6. There are so many variations on this theme that to discuss them all would require an essay (if not a book) in itself. Besides, such a task has already been undertaken and completed (with varying degrees of success) elsewhere. For instance, in a French context one can see both Keith Reader's Intellectuals and the Left in France Since May 1968 (London: Macmillan, 1987) and Jeremy Jennings' more recent 'Introduction: Mandarins and Samurais: The Intellectual in Modern France' in Jeremy Jennings ed. Intellectuals in Twentieth Century France: 
Mandarins and Samurais (London : Macmillan, 1993), 1-32). Nevertheless, at the risk of vastly oversimplifying the situation, it is perhaps sufficient to note some of the most frequently discussed contributions to this debate in recent years. In general, these have concentrated on the issues of the traditional 'committed' intellectual's apparent demise (Jean Baudrillard, Bernard-Henri Levy); intellectual delegitimation (Jean-François Lyotard; Zygmunt Bauman) redundancy (John Carey, Paul Johnston); and the need for 'a new type of intellectual' (Michel Foucault, Julia Kristeva). See Jean Baudrillard, op cit.; Bernard-Henri Levy's recent television series The Spirit of Freedom (initially broadcast in France, the first episode of this four-part series was broadcast in Britain on Channel Four on Thursda, 19 Nov, 1992; also B-H. Levy, Les Aventures de la liberte (Paris, 1991); JeanFrançois Lyotard, op cit; Zygmunt Bauman, Legislators and Interpreters: On Modernity, Postmodernity and Intellectuals (Cambridge: Polity, 1987); John Carey, The Intellectuals and the Masses: Pride and Prejudice Among the Literary Intelligentsia 1880-1939 (London: Faber and Faber, 1988); Paul Johnson, Intellectuals (London: Weidenfeld and Nicholson, 1988); Michel Foucault, op cit., Julia Kristeva, 'A New Type of Intellectual: The Dissident' in Toril Moi ed., The Kristeva Reader (Oxford: Blackwell, 1986).

7. Some of the main themes taken up from this point of view concern intellectual and cultural degeneration (Allan Bloom, Alain Finkielkraut) institutionalization (Russel Jacoby) and political responsibility (Edward W Said). See Allan Bloom, The Closing of the American Mind (Harmondsworth: Penguin, 1987); Alain Finkielkraut, The Undoing of the Thought, trans. Dennis O'Keefe (London: The Claridge Press, 1988); Russel Jocaby, The Last Intellectuals: American Culture in the Age of the Academe (New York: 1987); Edward W. Said, 'Opponents, Audiences, Constituencies and Community' in Hal Foster, ed., Postmodern Culture (London: Pluto Press, 1983), 135-159; and also Representations of the Intellectual (London: Vintage, 1994). Said writes: 'What could be less attractive and less true a couple of years after it was all the rage than Fukuyama's "end of history" thesis or Lyotard's account of the "disappearance" of the "grand narratives"' (E.W. Said, Representations of the Intellectual (London: Vintage, 1994), xv).

8. Gary Hall, 'Asking the question: what is an intellectual?'. parallax, 2, February 1996, 173-179.

9. Geoffrey Bennington, 'Postal Politics and the Institution of the Nation', Legislations: The Politics of 
Deconstruction (London: Verso, 1994), 240-257; also in Homi K. Bhabha, Nation and Narration (London: Routledge, 1990), 121-137.

10. Jean-François Lyotard (1979) The Postmodern Condition: A Report on Knowledge, trans. Geoffrey Bennington and Brian Massumi (Manchester: Manchester University Press, 1986).

11. Jean-François Lyotard, 'Defining the postmodern', in Postmodernism ICA Documents 4 and 5 (London, 1986), 6; cf. Geoffrey Bennington, op cit.

12. Jean-François Lyotard (1979) 'Answering the Question: What is Postmodernism?', The Postmodern Condition, op cit.; cf. Geoffrey Bennington, op cit.

13. Jean-François Lyotard, 'The Tomb of the Intellectual', op cit., 6. All further references will be cited in the text.

14. Jean-François Lyotard (1979) 'Answering the Question: What is Postmodernism?, The Postmodern Condition, op cit., 73.

15. Jean-François Lyotard, 'Re-writing Modernity', The Inhuman, trans. Geoffrey Bennington and Rachel Bowlby (London, Policy, 1991).

16. Terry Eagleton is just one of those to have traced the origins of post-structuralism to the 1968 student uprising in Paris. According to Eagleton:

Post-structuralism was a product of that blend of euphoria and disillusionment, liberation and dissipation, carnival and catastrophe, which was 1968. Unable to break the structures of state power, post-structuralism found it possible instead to subvert the structures of language. Its enemies, as for the later Barthes, became coherent belief-systems of any kind - in particular all forms of political theory and organisation which sought to analyze, and act upon, the structures of society as a whole. For it was precisely such politics which seemed to have failed: the system had proved too powerful for them, and the 'total' critique offered of it by a heavily Stalinized Marxism had been exposed as part of the problem, not as the solution. All such total systematic thought was now suspect as terroristic... (T. Eagleton, Literary Theory; An Introduction (Oxford: Blackwell, 1983) 142) 
17. For Allan Stoekl, for example, although the 'notion of the French intellectual is (or has become) radically incoherent', at some point in the past this figure 'was at least for one fleeting moment seemingly clearly formulated in regard to his or her political, polemical, and representational/representative function' (A. Stoekl, Agonies of the Intellectual: Commitment, Subjectivity, and the Performative in the Twentieth-Century French Tradition (Lincoln and London: University of Nebraska Press, 1992), 2).

18. For Edward W. Said, for example, the intellectual continues to be 'an individual endowed with a faculty for representing, articulating a message, a view, an attitude, philosophy or opinion to, as well as for, a public... (and who) does so on the basis of universal principles' (Edward W. Said, Representations of the Intellectual (London: Vintage, 1994), 9).

19. Jean-François Lyotard, 'Re-writing Modernity', The Inhuman, trans. Geoffrey Bennington and Rachel Bowlby (London: Polity, 1991). For a further example of Lyotard's 'rewriting' of the intellectual, see 'A Podium without a Podium: Television according to J F Lyotard', in JeanFrançois Lyotard: Political Writings, trans. Bill Readings and Kevin Paul Geiman (London: U.C.L. Press. 1993), 90-95.

20. Michel Foucault, 'Truth and Power', Power/ Knowledge: Selected Interviews and Other Writings 1972-77 (Brighton: Harvester, 1980), 126. Hereafter cited in the text as $\mathrm{P} / \mathrm{K}$.

21. Michel Foucault, 'Intellectuals and Power: A Conversation Between Michel Foucault and Gilles Deleuze', Language, Counter-Memory, Practice: Selected Essays and Interviews by Michel Foucault, Donald F. Bouchard, ed., trans. D.F. Bouchard and Sherry Simon (Ithaca, New York: Cornell University Press, 1977), 208. Hereafter cited in the text as I.P

22. Mark Foster, Critical Theory and Post-Structuralism: In Search of a Context (Ithaca and London: Cornell University Press, 1989), 49

23. A further example of Foucault's continued activity as a 'universal intellectual' can be found in his enthusiastic reaction (initially, at least) to the Revolution in Iran. See Michel Foucault, 'Iran: The Spirit of a World Without Spirit', in Politics, Philosophy, Culture: Interviews and Other Writings 1977-1984, ed. Lawrence D Kritzman (London: Routledge, 1988), 211-226. 
24. According to Collini, it is this "political" sense which has dominated French reflection on the subject'. What is more, 'since several of the most politically active French intellectuals have also been internationally known as intellectuals in the "cultural" sense, this has reinforced the image of France as the true home of the species' (S Collini, 'Intellectuals in Britain and France in the Twentieth Century: Confusions, Contrasts - and Convergences', in Jeremy Jennings, ed., op cit., 210). It is also this that gives rise to the idea that Britain has no 'real' intellectuals, Collini claims, since Britain has, by and large, not known such a tradition of political intervention by intellectuals conscious of their collective role' (210).

25. Jacques Derrida, 'From Restricted to General Economy: A Hegelianism Without Reserve', Writing and Difference, trans. Alan Bass (London: Routledge and Kegan Paul, 1978), 260. Derrida's other main texts on Hegel are: 'Positions', Positions, trans. and annotated by Alan Bass (Chicago: University of Chicago Press, 1981), 37-96; 'The Pit and the Pyramid: Introduction to Hegel's Semiology', Margins of Philosophy, trans. Alan Bass (Hemel Hempstead: Harvester Wheatsheaf, 1982), 71-108); and Glas, trans. John P. Leavey, Jr, and Richard Rand (University of Nebraska Press, 1986).

26. cf. Geoffrey Bennington, 'Derridabase', in Geoffrey Bennington and Jacques Derrida, Jacques Derrida (London: University of Chicago Press, 1994), 284-292.

27. Jacques Derrida, 'The Laws of Reflection: Nelson Mandela, In Admiration', trans. Mary Ann Caws and Isabelle Lorenz in For Nelson Mandela, ed. Jacques Derrida and Mustapha Tlili (New York: Seaver Books, 1987), 14, 17.

28. Jean-Paul Sartre, 'A Plea for Intellectuals', Between Existentialism and Marxism, trans. J Matthews (London: New Left Books, 1974). All further references will be cited in the text.

29. See Jean-Paul Sartre, 'Revolution and the Intellectual', Politics and Literature, trans. J. Calder and J A Underwood (London: Calder and Boyers, 1973), 13.

30. See Jean-Paul Sartre, 'A Friend of the People', Between Existentialism and Marxism, trans. J Matthews (London: New Left Books, 1974), 287. 
31. Jean-François Lyotard, The Differend: Phrases in Dispute (Manchester: Manchester University Press, 1988), 138, 190

32. Gilles Deleuze, 'Intellectuals and Power: A Conversation Between Michel Foucault and Gilles Deleuze', op cit., 209

33. Jean-Paul Sartre, 'Revolution and the Intellectual', op cit., 22/23.

34. Mark Foster, op cit., 44

35. Ibid., 37.

36. See Jean-Paul Sartre 'Revolution and the Intellectual' and 'A Friend of the People', op cit.

37. This is also the structure of the 'bridge' according to Heidegger, the 'hinge' according to Derrida, and the 'frontier' according to de Certeau. See Martin Heidegger, 'Building, dwelling, thinking', trans. Albert Hofstadter, in Martin Heidegger: Basic Writings, ed. D.F. Krell (London: Routledge and Kegan Paul, 1977), 330; Jacques Derrida, Of Grammatology, trans. Gayatri Chakravorty Spivak (Baltimore and London: Johns Hopkins University Press, 1976), 65-73; and Michel de Certeau, 'Spatial Stories', The Practice of Everyday Life, trans. Steven Randall (London: University California Press, 1984) 127.

38. See Derrida's argument with regard to Lacan's reading of Poe's 'The Purloined Letter' in 'The purveyor of truth', The Post Card, trans. Alan Bass (Chicago: University of Chicago Press, 1987). For Derrida, the conditions that make a letter's arrival possible also make its arrival impossible.

39. C.f. Samuel Weber, The Legend of Freud (Mineapolis: University of Minnesota Press, 1987) p.33.

I would like to acknowledge my debt to the work of the 'Frontiers' seminar which met at the University of Sussex from October 1989 to June 1992.

Accueil Surfaces | Table des matières | Recherche Surfaces Home Page | Table of Contents | Search

PUM | Livres | Revues | Publications électroniques | Vente et distribution 